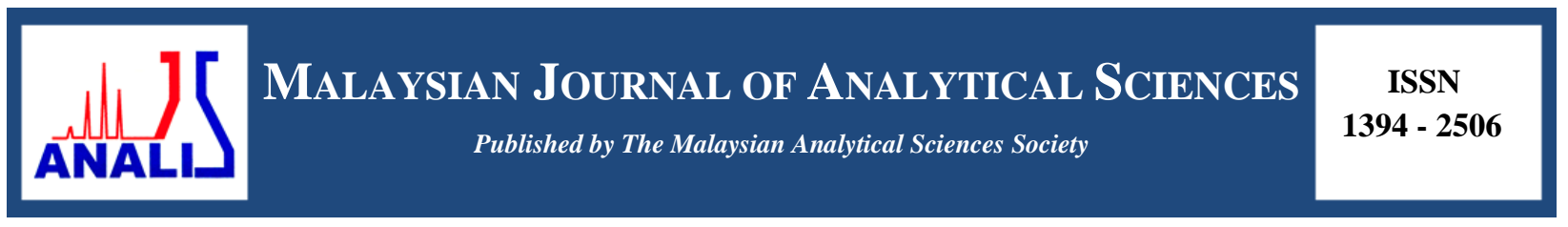

\title{
PRODUCTION OF COMPOST FROM NON-SHREDDED EMPTY FRUIT BUNCHES MIXED WITH ACTIVATED LIQUID ORGANIC FERTILIZER IN TOWER COMPOSTER
}

\author{
(Penghasilan Kompos dari Tandan Kosong Kelapa Sawit Tanpa Cincang Dicampur dengan Baja \\ Cair Aktif dalam Menara Komposter)
}

\author{
$\operatorname{Irvan}^{1,2}$, Muhammad Rahman ${ }^{1}$, Dedy Anwar ${ }^{1}$, Bambang Trisakti $^{1,2}$, Hiroyuki Daimon $^{3}$ \\ ${ }^{1}$ Chemical Engineering Department \\ ${ }^{2}$ Sustainable Energy and Biomaterial Center of Excellence \\ Universitas Sumatera Utara, Medan 20155, Indonesia \\ ${ }^{3}$ Department of Environmental and Life Sciences, \\ Toyohashi University of Technology, Toyohashi, 441-8580, Japan \\ *Corresponding author: irvan@usu.ac.id
}

Received: 13 April 2017; Accepted: 17 April 2018

\begin{abstract}
Empty fruit bunches (EFBs) with activated liquid organic fertiliser (ALOF) were composted in a tower composter. This study was conducted to evaluate the degradation of non-shredded EFB mixed with ALOF as an activator. The concrete tower composter with dimensions of $0.40 \mathrm{~m} \times 0.40 \mathrm{~m} \times 3.00 \mathrm{~m}$ was used to accelerate composting time by achieving thermophilic conditions. The moisture content (MC) of the compost was maintained at $55 \%-65 \%$. Compost quality, temperature, $\mathrm{pH}, \mathrm{MC}$, $\mathrm{C} / \mathrm{N}$ ratio, bacterial count $(\mathrm{BC})$ and electrical conductivity (EC) were recorded and evaluated. Composting was completed in 40 days, even though EFB turned to dark brown on day 10, indicating that the compost was mature. The quality of the final compost from day 10 to day 40 was slightly similar: $\mathrm{pH}$ of $7.6-8.4$, MC of $41.16 \%-58.44 \%$, C content of $20.27 \%-21.34 \%$, N content of $1.02 \%-1.25 \%, \mathrm{C} / \mathrm{N}$ ratio of $19.94-20.24$, BC of $17-41 \times 10^{6} \mathrm{CFU} \mathrm{g}^{-1}$ and $\mathrm{EC}$ of $3.74-4.90 \mathrm{dS} \mathrm{m}^{-1}$. These results suggested that the quality of the obtained compost satisfied the Indonesian National Standard.
\end{abstract}

Keywords: activated liquid organic fertiliser, composting, empty fruit bunches, tower composter

\section{Abstrak}

Buah tandan kosong (EFB) dengan baja organik cecair teraktif (ALOF) telah dikompos di dalam menara komposter. Kajian ini dijalankan untuk menilai data degradasi EFB yang tidak diparut bercampur dengan ALOF sebagai pengaktif. Penggunaan menara komposter, yang diperbuat daripada konkrit dengan dimensi $0.40 \mathrm{~m} \mathrm{~W}$ x $0.40 \mathrm{~m} \mathrm{~L} \mathrm{x} 3.00 \mathrm{~m} \mathrm{H}$, adalah untuk pecutan masa pengomposan bagi mencapai keadaan termofilik. Kandungan lembapan (MC) kompos dikekalkan dalam lingkungan 55 65\%. Kualiti kompos, suhu, $\mathrm{pH}$, kandungan lembapan, nisbah $\mathrm{C} / \mathrm{N}$, bilangan bakteria (BC), dan kekonduksian elektrik (EC) telah direkod dan dinilai. Proses pengomposan telah lengkap dalam masa yang singkat iaitu dalam 40 hari, dan pada hari yang ke-10, EFB telah bertukar warna menjadi coklat tua yang menunjukkan kematangan kompos. Kualiti kompos akhir dari hari 10 hingga ke hari 40 menunjukkan kualiti yang hampir sama iaitu pH antara 7.6 hingga 8.4; kandungan lembapan $41.16-58.44 \%$; C 20.27 - 21.34\%; N 1.02 - 1.25\%; nisbah C/N 19.94 - 20.24; bilangan bakteria 17 - 41 x 106 CFU g ${ }^{-1}$, dan kekonduksian elektrik 3.7 4.9 dS.m ${ }^{-1}$. Kualiti kompos keluaran yang diperolehi telah mencapai Piawai Kebangsaan Indonesia (SNI).

Kata kunci: baja organik cecair teraktif, pengomposan, buah tandan kosong, menara komposter 


\section{Irvan et al: PRODUCTION OF COMPOST FROM NON-SHREDDED EMPTY FRUIT BUNCHES MIXED WITH ACTIVATED LIQUID ORGANIC FERTILIZER IN TOWER COMPOSTER}

\section{Introduction}

Indonesia is currently one of the countries with the largest production of crude palm oil (CPO); in 2012, this country produced 23.5 million tons of CPO [1]. In addition to CPO, liquid and solid wastes are generated by palm oil mills (POMs). Large amounts of solid wastes, such as empty fruit bunch (EFB; 23\%), shell (5\%) and mesocarp fibre $(12 \%)$, are also obtained for every ton of EFB processed in POMs [2].

Composting is an alternative processing technology for solid and liquid wastes from POMs. Most EFBs are used as soil amendments in oil palm lands by placing EFBs around palm trees to provide a good environment for roots. However, this technique is costly in terms of labour and transportation [3]. EFB composting is usually time consuming because of environmental factors. The processing of EFB into compost has been extensively explored, and composting can be enhanced by introducing additional materials, such as animal waste $[4,5]$ and POME [6].

Activated liquid organic fertiliser (ALOF), which is used as a microbial source and moisture content (MC) buffer in composting, is obtained through the advanced fermentation of treated biogas effluent from an anaerobic digester. This effluent still possesses high nutrient and MC. Hence, ALOF addition to EFB may enrich composts with high nutrient and microbial sources. This research aimed to examine EFB composting in a tower composter and described the degradation of non-shredded EFB mixed with ALOF.

\section{Materials}

\section{Materials and Methods}

EFB (Sei Mangkei POM, Sumatera Utara, Indonesia) and ALOF (Biogas Pilot Plant, Universitas Sumatera Utara, Indonesia) were used as raw materials, and their characteristics are presented in Table 1.

Table 1. Characteristic of EFB and ALOF

\begin{tabular}{llcc}
\hline No. & Parameters & EFB & ALOF \\
\hline 1 & Moisture $(\%)$ & 43.83 & - \\
2 & $\mathrm{pH}$ & 7.80 & 8.09 \\
3 & $\mathrm{C}(\%)$ & 33.15 & 0.58 \\
4 & $\mathrm{~N}(\%)$ & 0.99 & 0.10 \\
5 & $\mathrm{C} / \mathrm{N}$ & 33.48 & 5.80 \\
6 & Water Holding Capacity $(\%)$ & 62.00 & - \\
7 & $\mathrm{P}_{2} \mathrm{O}_{5}(\%)$ & - & 0.016 \\
8 & $\mathrm{~K}_{2} \mathrm{O}(\%)$ & - & 0.167 \\
9 & $\mathrm{COD}(\mathrm{mg} / \mathrm{l})$ & - & 1.580 \\
\hline
\end{tabular}

\section{Equipment}

The main equipment used in this study was a box-shaped composter tower constructed under a shade and a cement base at the Pusdiklat LPPM-Universitas Sumatera Utara, Indonesia. The composter tower measured $3 \mathrm{~m}$ in height and consisted of a $0.4 \mathrm{~m} \times 0.4 \mathrm{~m}$ square pedestal. The composter was equipped with two $0.11 \mathrm{~m} \mathrm{x} 0.11 \mathrm{~m}$ windows and a $0.40 \mathrm{~m} \times 0.40 \mathrm{~m}$ manhole, which were used for sampling and product harvesting, respectively. Fifteen holes $(1.905 \mathrm{~cm})$ were made on each wall of the composter for oxygen intake (aeration) and inserted with a digital thermometer to measure the temperature of the composting material in the composter. A detailed sketch of the composter is presented in Figure 1.

\section{Composting process}

Composting was initiated by measuring the total weight of the non-shredded EFB. The EFB was poured with ALOF until the MC of the compost reached 55\%-65\%. No-turn composting operation was required during the process, but ALOF was poured again into the composter when the MC was too low to maintain the MC at $55 \%-65 \%$. 


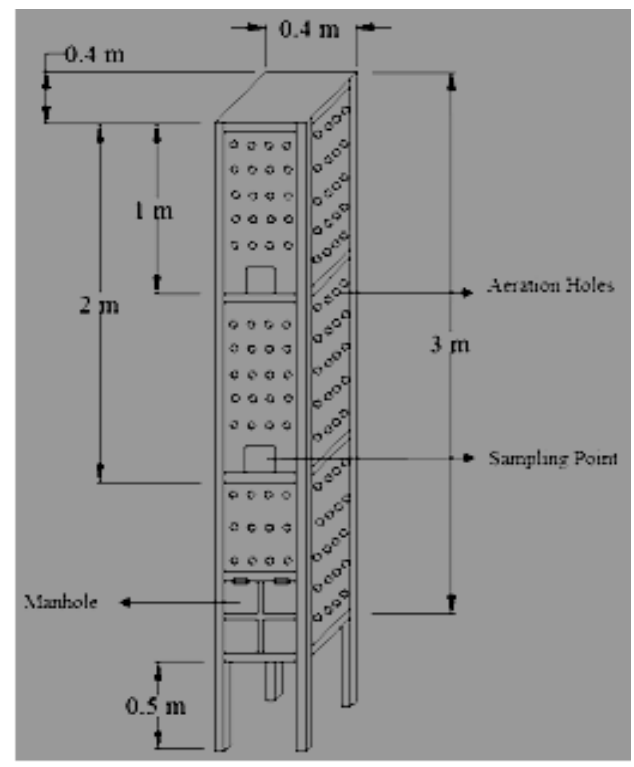

Figure 1. The tower composter

\section{Sampling and Data Collection}

Samples $(20 \mathrm{~g})$ were collected from the sampling window and stored at $4{ }^{\circ} \mathrm{C}$. Temperature was measured by inserting a digital thermometer into the thermometer hole. The following data were obtained: temperature, $\mathrm{MC}, \mathrm{pH}$, $\mathrm{C} / \mathrm{N}$ ratio and compost quality. Pile temperature was measured twice a day (morning and afternoon). Pile MC was also determined every 5 days via a drying oven method. $\mathrm{pH}$ was identified every 2 days. $\mathrm{C}$ and $\mathrm{N}$ contents were recorded on days $0,10,30$ and 40 of the treatment through the Walkley-Black and Kjeldahl method, respectively. Bacterial growth and electrical conductivity (EC) were monitored on days $0,10,30$ and 40 of the treatment by conducting bacterial count (BC) analysis and by using an EC meter, respectively.

\section{Temperature profile}

\section{Results and Discussion}

Temperature is the most important parameter to be measured during composting [7]. The average temperature profile in the morning and in the afternoon at heights of 0,1 and $2 \mathrm{~m}$ of the compost pile from the bottom of the composter is presented in Figure 2. The initial temperature of the compost was $27{ }^{\circ} \mathrm{C}$. Composting started once the compost was mixed with ALOF. After 24 days of operation, the average temperatures of the composting material at 0,1 and $2 \mathrm{~m}$ increased to $51.5 \pm 0.71{ }^{\circ} \mathrm{C}, 60.75 \pm 0.35^{\circ} \mathrm{C}$ and $52.5 \pm 0.71{ }^{\circ} \mathrm{C}$, respectively.

At the beginning of composting, the temperature increased from atmospheric temperature $\left(27^{\circ} \mathrm{C}\right)$ to thermophilic temperatures of $51.5 \pm 0.71{ }^{\circ} \mathrm{C}, 60.75 \pm 0.35{ }^{\circ} \mathrm{C}$ and $52.5 \pm 0.71{ }^{\circ} \mathrm{C}$ at heights of 0,1 and $2 \mathrm{~m}$, respectively. The temperatures decreased and fluctuated from day 5 and finally remained almost constant after day 30 of the treatment. This result was consistent with those of Shen et al. [8] and Hock et al. [9], who reported that compost temperatures rapidly increase and then slowly decrease. This finding indicated that composting slowed down as nutrient availability became depleted. 


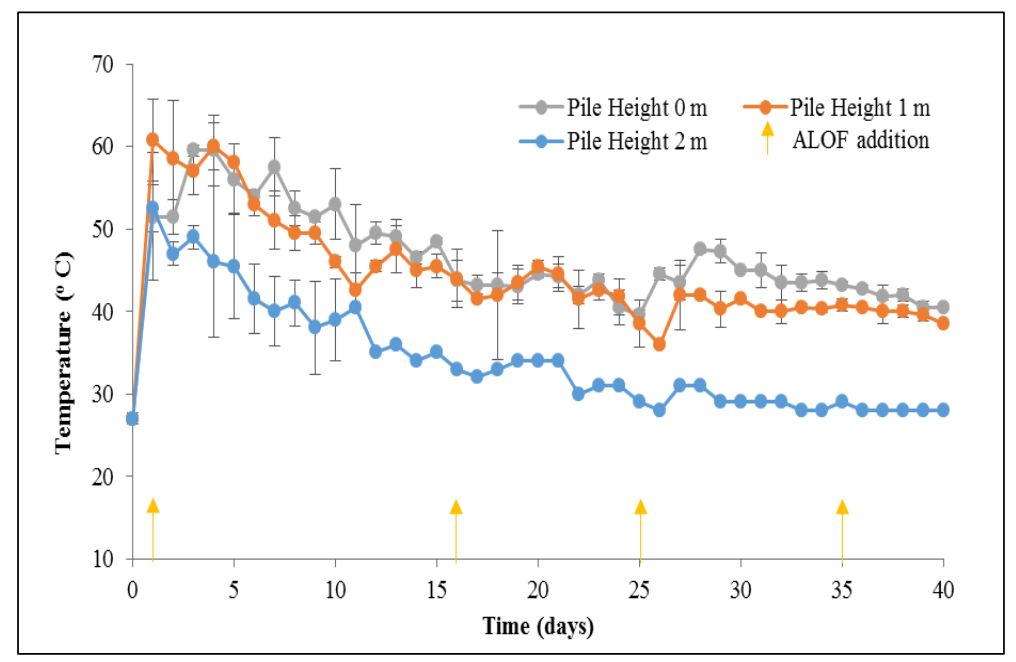

Figure 2. Temperature profiles during composting

\section{MC profile}

$\mathrm{MC}$ is one of the important factors that must be maintained during composting [10]. The MC profiles at heights of 0,1 and $2 \mathrm{~m}$ of the compost pile from the composter bottom are presented in Figure 3 . The initial MC of EFB was 43.83\%. After EFB was mixed with ALOF, the MCs changed to $64.76 \%, 63.72 \%$ and $61.78 \%$ at 0,1 and $2 \mathrm{~m}$, respectively. MC also fluctuated during composting. To maintain MC at 55\% - 65\%, we added ALOF on days 1, 16,25 and 35 of the treatment. MC evaluation at $2 \mathrm{~m}$ of compost was terminated on day 11 because shrinkage occurred in the composting material.

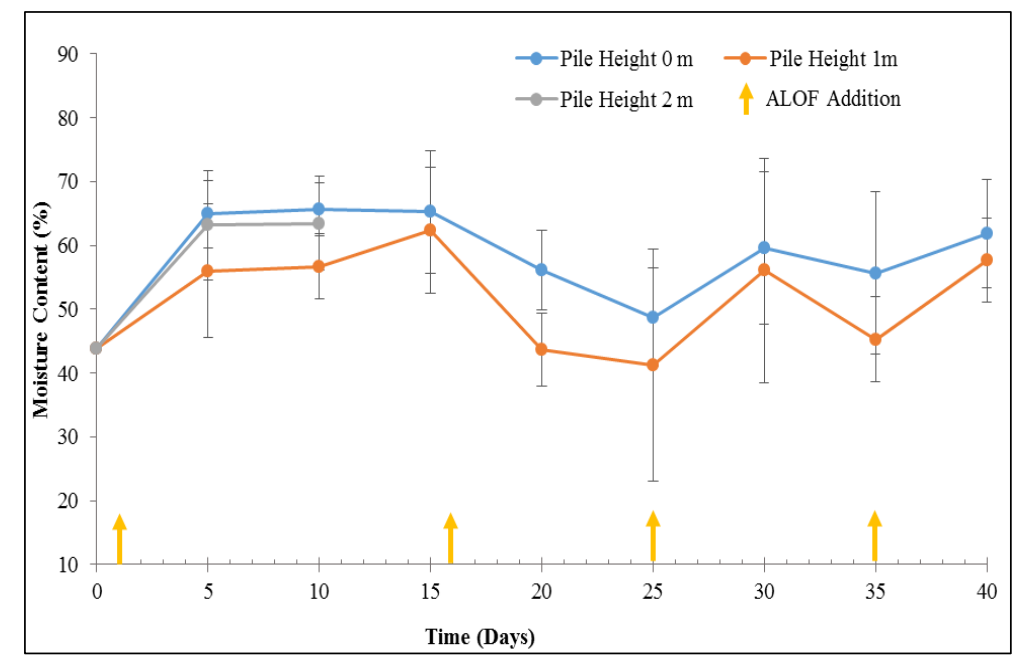

Figure 3. Moisture content profiles

The final MCs of the compost after 40 days at 1 and $2 \mathrm{~m}$ were $65.68 \%$ and $51.2 \%$ (average: $58.44 \%$ ), respectively, and they were similar to those of Hock et al. [9] and Baharuddin et al. [10], who obtained final MCs of approximately $50 \%$ after 39 days and 52\%, respectively. Tiquia et al. [11] demonstrated that the MC of a composting material must be maintained at $40 \%-60 \%$ to favour microbial survival. An MC of $>80 \%$ can kill aerobic microbes because of the lack of oxygen. 


\section{pH profile during composting process}

The $\mathrm{pH}$ profile during composting is presented in Figure 4. The $\mathrm{pH}$ during 40 days of composting ranged from 7.8 to 8.4 , indicating that the operational conditions were likely alkaline. The alkaline condition of a composting material is good for composting because this $\mathrm{pH}$ may inhibit the growth of pathogens, such as fungi, which can survive under acidic conditions [12].

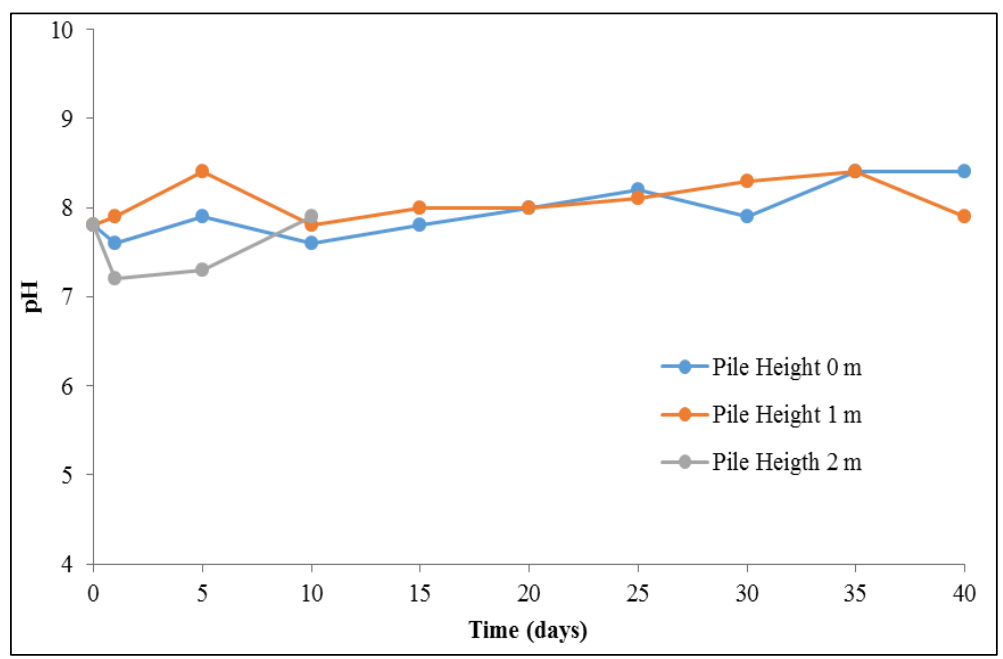

Figure 4. $\mathrm{pH}$ profiles

The $\mathrm{pH}$ of the pile at each height fluctuated slightly from day 0 to day 25 and became relatively constant until day 40. Changes in $\mathrm{pH}$ during composting are caused by microbial activity [13, 14]. In the first 5 days, $\mathrm{pH}$ increased from 7.8 to 8.6 because $\mathrm{N}$ is transformed into $\mathrm{NH}_{3}$ or $\mathrm{NH}_{4}{ }^{+}$via ammonification [13]. From day 5 to day 10, $\mathrm{pH}$ likely decreased to $\mathrm{pH} 7.6$ because of the volatilisation of ammonium and the release of hydrogen ions as a result of nitrification [10]. The $\mathrm{pH}$ of the final mature compost was 8.4.

\section{Profile of BC}

Microbial growth during composting was observed by analysing BC. The number of microbial colonies and the average temperature of the composting material are presented in Figure 5.

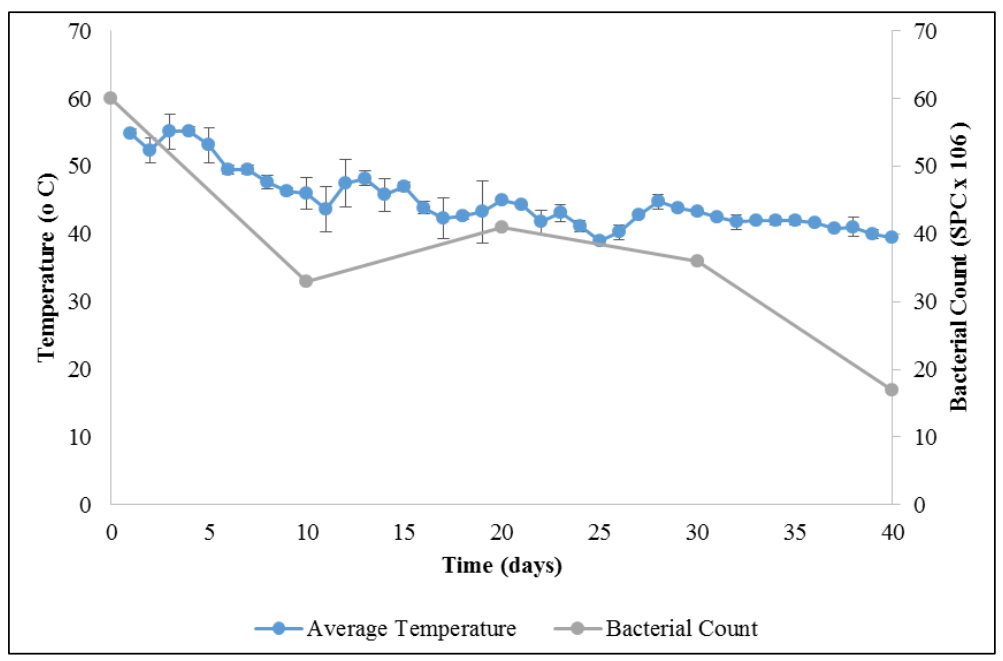

Figure 5. Profiles of bacterial count and temperature during composting 


\section{Irvan et al: PRODUCTION OF COMPOST FROM NON-SHREDDED EMPTY FRUIT BUNCHES MIXED WITH ACTIVATED LIQUID ORGANIC FERTILIZER IN TOWER COMPOSTER}

Two states of microbial growth during composting were observed on the basis of the average temperature of the composting material: thermophilic state $\left(1^{\text {st }}\right.$ to $\left.15^{\text {th }}\right)$ and mesophilic state (day 16 to day 40 ). The initial $\mathrm{BC}$ was $60 \mathrm{x}$ $10^{6} \mathrm{CFU} \mathrm{g}{ }^{-1}$. After the thermophilic state was initiated on day 1 , the BC drastically decreased because the total BC was initially dominated by mesophilic bacteria, and most of them died as the temperature increased and reached the thermophilic state. From day 10 to day 20, the BC increased because the thermophilic and mesophilic bacteria already survived in the thermophilic state and started to grow. From day 30 to day 40, the BC slowly decreased as nutrient availability decreased.

\section{Compost analysis based on $\mathrm{C} / \mathrm{N}$ ratio}

To determine the quality of the compost produced during composting, we measured the $\mathrm{C} / \mathrm{N}$ ratio in triplicate. The $\mathrm{C} / \mathrm{N}$ ratio profile during composting is presented in Figure 6.

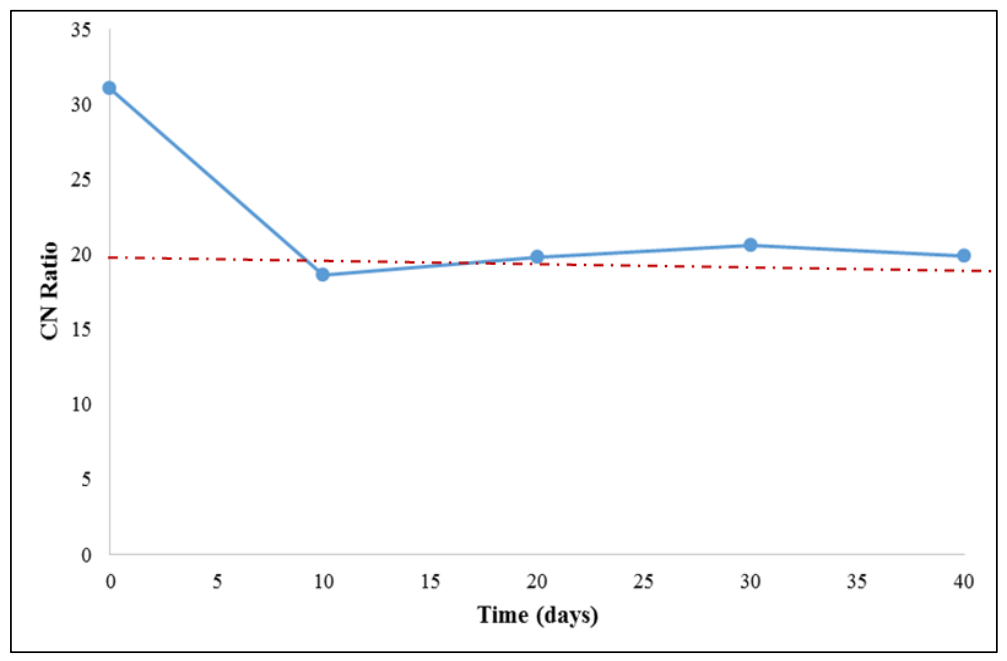

Figure 6. $\mathrm{C} / \mathrm{N}$ ratio changes during composting

The $\mathrm{C} / \mathrm{N}$ ratio is one of the important indicators that reflect the maturity of compost $[6,15]$. In our study, this parameter was measured on days $0,10,20,30$ and 40 of the treatment. The initial $\mathrm{C} / \mathrm{N}$ ratio of EFB was 33.48. After 10 days of composting, the $\mathrm{C} / \mathrm{N}$ ratio significantly decreased to 18.64 . From day 20 to day 40 , the $\mathrm{C} / \mathrm{N}$ ratio remained relatively constant at $19-20$. At the end of composting, the $\mathrm{C} / \mathrm{N}$ ratio was 19.94 , indicating that the compost matured after 10 days because the $\mathrm{C} / \mathrm{N}$ ratio of a standard matured compost is between 10 and $20[6,16]$. The decrease in the $\mathrm{C} / \mathrm{N}$ ratio was due to the decrease in $\mathrm{C}$ content or the increase in $\mathrm{N}$ content during composting. This phenomenon occurred because of the decomposition of organic materials during microbial activity [9, 17].

\section{Compost analysis based on EC}

EC reflects the level of salinity of a compost product and indicates possible phytotoxic or phyto-inhibitory effects [18]. The changes in EC during composting are presented in Figure 7. The initial EC of EFB was $6.72 \mathrm{dS} \mathrm{m}^{-1}$, but this value decreased to $4.30 \mathrm{dS} \mathrm{m}^{-1}$ after 20 days of composting. On day 30 , the EC increased to $4.42 \mathrm{dS} \mathrm{m}^{-1}$ and then decreased to $3.74 \mathrm{dS} \mathrm{m}^{-1}$ at the end of composting.

The decrease in EC during composting is a direct result of the increasing concentrations of nutrients, such as nitrate and nitrite [19]. The increase in EC may be due to the release of mineral salts, such as ammonium and phosphate ions, through the decomposition of organic substances [18]. The results of the complete analysis of compost quality are presented in Table 2. 


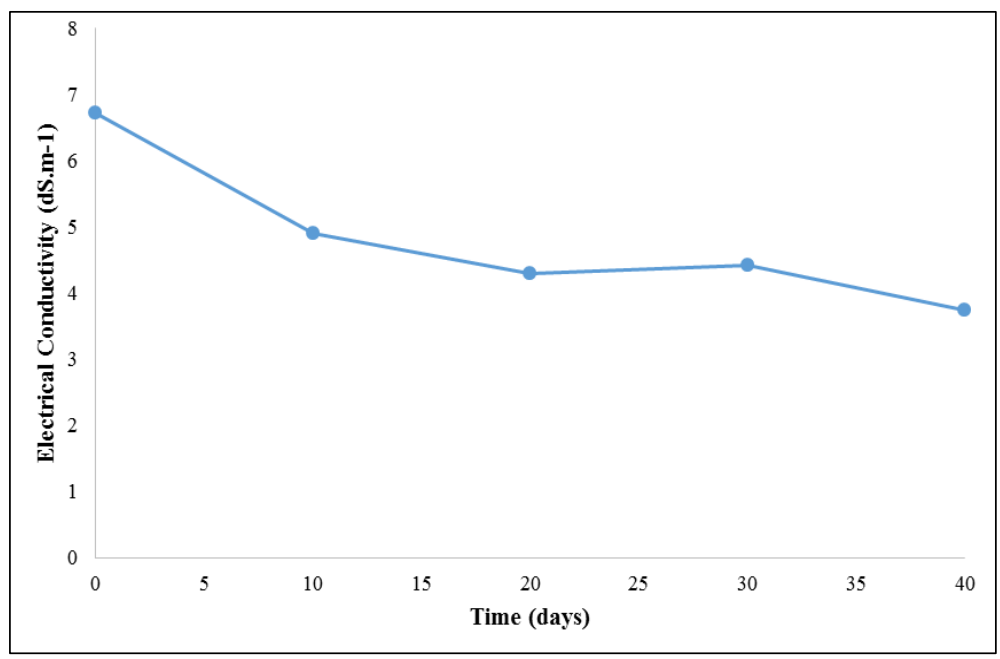

Figure 7. Changes in electrical conductivity

Table 2. Compost quality analysis

\begin{tabular}{llcc}
\hline \multirow{2}{*}{ No } & \multirow{2}{*}{ Parameters } & \multicolumn{2}{c}{ Composting Material } \\
\cline { 3 - 4 } & & Start up & Day 40 \\
\hline 1 & Moisture (\%) & 43.83 & 58.44 \\
2 & $\mathrm{pH}(\%)$ & 7.80 & 8.40 \\
3 & Water Holding Capacity (\%) & 62.00 & 64.00 \\
4 & $\mathrm{C}(\%)$ & 37.89 & 21.34 \\
5 & $\mathrm{~N}(\%)$ & 1.22 & 1.07 \\
6 & $\mathrm{C} / \mathrm{N}(\%)$ & 31.06 & 19.94 \\
7 & $\mathrm{P}(\%)$ & 0.201 & 0.091 \\
8 & $\mathrm{~K}(\%)$ & 0.157 & 0.951 \\
9 & $\mathrm{Na}(\mathrm{ppm})$ & 0.102 & 0.059 \\
10 & $\mathrm{Ca}(\mathrm{ppm})$ & 1.759 & 2.043 \\
11 & $\mathrm{Mg}(\mathrm{ppm})$ & 0.537 & 0.527 \\
12 & $\mathrm{Cd}(\mathrm{ppm})$ & 0.894 & 0.437 \\
13 & $\mathrm{Cu}(\mathrm{ppm})$ & 0.673 & 0.078 \\
14 & $\mathrm{Fe}(\mathrm{ppm})$ & 1.073 & 0.051 \\
15 & $\mathrm{~Pb}(\mathrm{ppm})$ & 1.246 & 0.080 \\
16 & $\mathrm{Zn}(\mathrm{ppm})$ & 2.370 & 0.052 \\
17 & $\mathrm{Oil} \mathrm{\&} \mathrm{Grease} \mathrm{( \% )}$ & 2.15 & 1.43 \\
\hline
\end{tabular}

\section{Conclusion}

The composting of non-shredded EFB mixed with ALOF as microbial and nutrient sources and MC buffer in a boxshaped tower composter $(0.4 \mathrm{~m}$ width $\mathrm{x} 0.40 \mathrm{~m}$ length $\mathrm{x} 3.00 \mathrm{~m}$ height) could produce mature compost for 10 days. The slight differences in the C/N ratio from 18.15 to 19.94 and the EC from $3.74 \mathrm{dS} \mathrm{m}^{-1}$ to $4.90 \mathrm{dS} \mathrm{m}^{-1}$ indicated that the quality of the compost on day 10 was similar to the quality of the compost on day 40. 


\section{Acknowledgement}

This research was financially supported by Hibah BP-PTN Universitas Sumatera Utara, contract no: 6049/UN5.1.R/PPM/2016, date July19 ${ }^{\text {th }}, 2016$.

\section{References}

1. Irvan, Trisakti, B., Sosanty, F. and Tomiuchi, Y. (2016). Effect of discontinuing sodium bicarbonate on fermentation process of palm oil mill effluent. Asian Journal of Chemistry, 28(2): 377 - 380.

2. Trisakti, B., Lubis, J., Husaini, T. and Irvan (2017). Effect of turning frequency on composting of empty fruit bunches mixed with activated liquid organic fertilizer. IOP Conference Series: Materials Science and Engineering, 180: 012150.

3. Kavitha, B., Jothimani, P. and Rajannan, G. (2013). Empty fruit bunch - a potential organic manure for agriculture. International Journal of Science, Environment and Technology, 2(5): 930 - 937.

4. Suhaimi, M. and Ong, H. K. (2001). Composting empty fruit bunches of oil palm. food and fertilizer technology centre. Retrieved from http://www.agnet.org/library/eb/505a/pdf. [Access online 11 December 2013].

5. Thambirajah, J. J., Zulkali, M. D. and Hashim, M. A. (1995). Microbiological and biochemical changes during the composting of oil palm empty fruit bunches - effect of nitrogen supplementation on the substrate. Bioresource Technology, 52(2): 133 - 144.

6. Baharuddin, A. S., Wakisaka, M., Shirai, Y., Abd-Aziz, S., Abdul Rahman, N. A. and Hassan, M. A. (2009). Co-composting of empty fruit bunches and partially treated palm oil mill effluents in pilot scale. International Journal of Agricultural Research, 4(2): 69 - 78.

7. Saiidi, S., Hasani, M., Hashemi, J. and Amini, M. (2012). Investigation of optimum conditions of cocomposting process by using of sewage sludge and municipally waste. The $1^{\text {st }}$ International and the $4^{\text {th }}$ national congress on recycling of organic waste in agricultural, Isfahan, Iran. 26 - 27 April 2012.

8. Shen, Y., Rein, L., Li, G., Chen, T. and Guo, R. (2010). Influence of aeration on $\mathrm{CH}_{4}, \mathrm{~N}_{2} \mathrm{O}$ and $\mathrm{NH}_{3}$ emissions during aerobic composting of a chicken manure and high $\mathrm{C} / \mathrm{N}$ waste mixture. Waste Management, 31(1): 33 38.

9. Hock, L. S., Baharuddin, A. S., Ahmad, M. N., Md Shah, U. K., Rahman, N. A. A., Abd-Aziz, S., Hassan, M. A. and Shirai, Y. (2009). Physicochemical changes in windrow co-composting process of oil palm mesocarp fiber and palm oil mill effluent anaerobic sludge. Australian Journal of Basic and Applied Sciences, 3(3): 2809 $-2816$.

10. Baharuddin, A. S., Hook, L. S., Yusof, M. Z. M., Rahman, N. A. A., Shah, U. K. M., Hasan, M. A., Wakisaka, M., Sakai, K. and Shirai, Y. (2010). Effects of palm oil mill effluent (POME) anaerobic sludge from $50 \mathrm{~cm}^{3}$ of closed anaerobic methane digested tank on pressed-shredded empty fruit bunch (EFB) composting process. African Journal of Biotechnology, 9(16): 2427 - 2436.

11. Tiquia, S. M., Tam, N. F. Y. and Hodgkiss, I. J. (1997). Effects of turning frequency on composting of spent pig-manure sawdust litter. Bioresource Technology, 62: 37 - 42.

12. Saidi, N., Chérif, M., Jedidi, N., Mahrouk, M., Fumio, M., Boudabous, A. and Hassen, A. (2008). Evolution of biochemical parameters during composting of various wastes compost. American Journal of Environmental Sciences, 4(4): 332 - 341.

13. Kananam, W., Suksaroj, T. T. and Suksaroj, C. (2011). Biochemical changes during oil palm (Elaeis guineensis) empty fruit bunches composting with decanter sludge and chicken manure. Science Asia, 37: 17 23.

14. Sundberg, C., Smars, S. and Jonsson, H. (2004). Low $\mathrm{pH}$ as an inhibiting factor in the transition from mesophilic phase in composting. Bioresource Technology, 95: $145-150$.

15. Nutongkaew, T., Duangsuwan, W., Prasertsan, S. and Prasertsan, P. (2011). Production of compost from palm oil mill biogas sludge mixed with palm oil mill wastes and biogas effluent. TIChE International Conference, Hatyai, Songkhla, Thailand. 10 - 11 November 2011.

16. Zahrim, A. Y. and Asis, T. (2010). Production of non-shredded empty fruit bunch semi-compost. Journal-The Institution of Engineers, 71(4): 11 - 17.

17. Razali, W. A. W., Baharuddin, A. S., Talib, A. T., Sulaiman, A., Naim, M. N., Hassan, M. A. and Shirai, Y. (2012). Degradation of oil palm empty fruit bunches (OPEFB) fibre during composting process using in vessel composter. BioResources, 7(4): 4786 - 4805. 
18. Gao, M., Liang, F., Yu, A., Li, B. and Yang, L. (2009). Evaluation of stability and maturity during forcedaeration composting of chicken manure and sawdust at different $\mathrm{C} / \mathrm{N}$ ratios. Chemosphere, 78 (5): 614 - 619.

19. Pathak, A. K., Singh, M. M., Kumara, V., Arya, S. and Trivedi, A. K. (2012). Assessment of physico-chemical properties and microbial community during composting of municipal solid waste. Recent Research in Science and Technology, 4(4): 10 - 14. 